Nikonenko O. S. ${ }^{1}$, Salyutin R. V. ${ }^{2}$, Komarov M. P. ${ }^{3}$, Palyanitsa S. S. ${ }^{2}$

${ }^{1}$ Medical Academy for Postgraduate Education, Zaporizhzhya, Ukraine

${ }^{2}$ Coordination Center for Transplantation of Organs, Tissues and Cells, Health Ministry of Ukraine, Kyiv, Ukraine

${ }^{3}$ Health Ministry of Ukraine, Kyiv, Ukraine

e-mail: r.salutin@mail.ru

\title{
ORGAN TRANSPLANTATION SERVICE IN UKRAINE - DEVELOPMENT PROBLEMS AND WAYS OF OVERCOMING
}

\section{ABSTRACT}

This review describes the present day state of organ and cell transplantation services in Ukraine. Established have been the main challenges of their development and ways of overcoming. The creation of the National Agency on the transplantation and donation would give an opportunity to determine a single structure responsible for the development of all directions of transplantation service and would allow provide functioning of public health care and research institutions extremely necessary for institute of transplantation coordinators. Some kinds of activity need updating and elaboration of new normative documents. It is only clear-cut regulations and control over activities of organ transplantation that would prevent possible legal infringements in this sphere, thus allowing medical professionals in the field of organ transplantation service in Ukraine work on good international standards.

KEYWORDS: transplantology, cell and organ transplantation, hematopoietic stem cells, Register of the Donors.

Clinical organ transplantation is recognized as one of the most important disciplines of medicine developing very dynamically worldwide. The results of analysis of the tendencies of health services and research attainments show that after $15-20$ years 50 to 60 percent of all surgical interventions will be done with transplantation of organs, cells and bioimplants, including xenografts.

Over the last decade the number of organ transplantations increased dramatically. Especial advances in this area have been done in such countries as Spain (within 2012 year more than 3,500 transplantations, most of which were obtained from cadavers), the USA (over 24,000 transplanted organs of which 18,000 cadaveric) and the countries of Asian region (South Korea, Japan and China). We can witness a considerable increase in transplantation of tissue and especially cell grafts. Transplantation of the cornea, bone marrow, tissue complexes or bioimplants has become a routine procedure and the number of organ transplantations exceeds hundreds of thousands.

Regrettably the state of national transplantology reveals a sober lack of progress. It needs to be recognized that the cradle of al aspects of transplantology is seen outside Ukraine. Despite the fact that organ transplantation (donor cadaver kidney), first in the world was performed by our countryman Yu. Yu. Voronoy as far as in 1933 in Kharkov or Kherson (according to other sources), the number of organ transplantations within the years of Independence of Ukraine makes no less than 129 per year. In our 8 regional organ transplantation centers (for comparison 40 transplantation centers per 47 million of population in
Spain) the average number of transplantations per year varies between 98 and 115. Notably, the majority operations for kidney transplantation are performed with the use of related donor material. The annual number of liver transplantations varies from 12 to 15 , of which $95 \%$ are performed with the use of living donor organs. Within a period since 2001 year only 8 heart transplants and 3 kidney-pancreas complexes have been done, whereas there is a greater need in organ transplantations. More than 2,500 citizens of Ukraine need kidney and over 1,000 patients need liver and heart transplantations per year.

The worry is that the absence of donor organs forces patients stay on constant non-effective conservative treatment that causes social and labor disintegration of patients and lies a burden on state budget (by way of social payments on disability, loss of work-able individuals, treatment abroad, etc). The apparatus dialysis per patient costs 150,000-170,000 Hryvnas and on peritoneal more than 190,000 Hryvnas. The cost of kidney transplantation with drug provision for first post-operation year makes $160,000-180,000$ Hryvnas, and during the subsequent years (immune suppression) from 70,000 to 85,000 Hryvnas, depending on the chosen treatment scheme.

So, the example of kidney transplantations indicates the undeniable economic expedience of organ transplantations solely from the position of material provision, not to mention so important fact as social and labor integration of patients in society.

Significant and socially appreciable problem is the transplantation of bone marrow cells. Currently, there are only 4 centers for bone marrow 
cells transplantation functioning in Ukraine. At the same time, according to the data of the European Group for Blood and Marrow Transplantation (EBMT) there are altogether 450 transplantation centers in 31 European countries. For comparison, in Ukraine the number of transplantations makes no more than 5 and in the countries of Europe over 200,000 per one million of the population. Every year more than 1500 patients need bone marrow transplantation. Of them 100 to 200 patients need nonrelated donor transplants. Besides, no transplantations from non-related donor are performed in Ukraine. As for the number of bone marrow cell transplants from related donor does not exceed a dozen per year.

In view of complicated domestic situation with cell transplantation, the citizens are made seek a solution of this matter by way of being sent for treatment abroad that primarily lays a burden on the state budget and causes social tension in society. Noteworthy is the fact that the cost of transplantation from a non-related donor in Europe makes more than 200,000 Euros while the similar operation made in Ukraine costs nearly 500,000 Hryvnas. The base founded in 2009 year for the purpose of obtaining donor anatomic material, The Ukrainian Register of the Donors of Hematopoietic Bone Marrow Stem Cells, is currently lists only 73 potential donors thus making it, in fact, inappropriate for providing donor material of cell transplants.

There are several reasons that make domestic transplantation service so critical. The foremost and primary reason for discontinuation of such service is the absence of a clear-cut management vertical, i.e. a sole organ coordinating activities of all directions of the transplantation service.

The Coordination Center for transplantation of organs and tissues affiliated with the Health Ministry of Ukraine (hereinafter Center) founded in 1994 was the first structure in the former USSR that coordinated activities linked with transplantation. Over the years of its functioning the Center was headed by the prominent leaders of national medicine such V. F. Sayenko, V. I. Tsymbaliuk and others. Under their leadership, the normative-legal base for transplantation service was created and the priority directions of its development and modernization were established. Within the framework of its competence the Center gives permission and controls the fulfillment of the trials on cell and tissue transplants, modernizes the existing and develops the new normativelegal acts which determining the principles of transplantation service, controls the fulfillment of the State purpose-designed social programs on transplantation, etc.

However the existing legislation (The Law of Ukraine on Central Bodies of the Executive Power) deprived the right of the Center to coordinate and control transplantation servicing and turned it, in fact, into a scientificpractical institution dealing with research activities. The key to the solution of this problem lies in the legislative area, namely in reorganization of the Center into a National Agency on the transplantation and donation. The status of the executive power body would give an opportunity to determine a single structure responsible for the development of all directions of transplantation service, including provision of the donor stage (search for post-mortem donor, logistic functions, etc) and, with the help of its own laboratory, control the quality and safety of anatomic materials designed for transplantation and HLA typing of donor bone marrow specimen.

In addition, the National agency on transplantology would allow provide functioning of public health care and research institutions serving like anatomic material removal bases, extremely necessary for institute of transplantation coordinators. The latter have the task to select potential donors amongst the individuals who underwent a diagnosis of brain death and further coordinate activities of the staff of the organ removal bases and transplantation teams. In the instance of Spain it is the creation and functioning of transplant-coordination service that allowed this country occupy first place in terms of the number of cadaver organ transplantations.

The financing remains to be the "Achilles heel" of the national transplantology. The state social program "Transplantation 2008-2012" was funded by $55 \%$ of the planned amount. To say more, many items, social advertising included, were removed from this program. The state provides finance only to purchase immune suppressive preparations and consumables for hemodialysis and partly equipment. Provision of development of regional transplantation units lays a burden on local budgets which cover payment only of the salaries and wages. Financing of the process of anatomic material removal (compensation to public health bodies for consumables, equipment amortization, etc) is not envisaged by the state budget that has a negative influence on the number of cadaveric transplantations.

The solution of this question is only possible by turning attention of the state and society to the challenges and perspectives of transplantation service development in Ukraine. The next step will be the opening of state-owned transplantation centers, say, in Kiev on the base of the 0. 0 . Shalimov State Institute of Surgery and Transplantology of the National Academy of Medical Sciences and in the town of Zaporizhzhya. The creation of "mother center" along with the bases for anatomic material removal attached to them (a so-called "transplantation district") equipped and provided by the state will give the opportunity at first stages to satisfy the first need in organ transplantation, form scientific-practical and methodological transplantation schools and pass over knowledge and skills to the regional transplantation centers.

Analogous to the creation of "mother organ transplantation center" it would be worthwhile to consider a question concerning creation, at the first stage, of two centers for transplantation of hematopoietic stem cells and, on their base, to develop and improve technologies for all kinds of cell transplantation primarily from allogeneic related donors. On gaining experience and training of personnel, the above-said centers would perform only complicated types of cell transplantations like grafting of cell specimen from allogeneic non-related donors while the autologous transplantations would be performed in the hematology departments at big regional hospitals. Such scheme would allow give highly-qualified and specialized assistance to the greater number of patients with oncohematologic pathology.

"Transplantation illiteracy" extremely spoils the vision of society and, regrettably, medical personnel concerning transplantation and related procedures and, surely, occupies a second place after financing in terms of the significance in the development of national transplantation service. Media warms up "black" interest to transplantation, increase aggressive attitude of society to this field thus making harm to national interests and doom to death of thousands of the citizens of Ukraine.

The negative way in which the media presents the issues about transplantation in this country leads to non-accepting of cadaveric donation, the appearance of histories about "black transplantologists", suspicious and faulty "interest" of the legal bodies to this field, the appearance of the criminal affairs of physicians or court-medical experts. After all, none of the affairs of "black transplantologists" has finished with criminal outcome for the representatives of transplantation service. However the negative resonance in society remains and how it is possible to rehabilitate medical professionals after groundless accusation.

Financial hunger and certain subjective reasons limit teaching of the course "Transplantology" in medical educational institutions, colleges, post-diploma education courses that leads to negative and spoiled vision and disapproving attitude of medical workers toward transplantation service.

To solve the problem of socio-educational character is only possible via the efforts of state bodies and public organizations. It is necessary to involve religious and charitable funds, including those on the legislative level. Of today the above-listed structures refuse and reject social work and solve only minor local problems, by sending various appeals and requirements to the ministry, spoiling the concept of civil and charitable organizations.

Under circumstances, the socially directed information campaign like road banners, information articles and television programs about public usefulness and benefits of organ donation will guarantee to promote information-educational activity relative transplantation service and to increase the number of transplantations. 
It has been the massive social active program that allowed Spain, Poland, Byelorussia and other countries take lead in terms of increasing the number of transplantations. Notably that some of the countries until recently did not perform transplantations at all. It is worth noting that those were charitable and public organizations that played an essential role in the implementation of social programs in the above-said countries, while the country only coordinated and directed their efforts.

Of great importance in the matter of developing transplantation service is the normative-legislative base. Within the years of the existence of transplantation service, the Center elaborated about two dozens of normative acts which regulate activities of the transplantation centers and bases for anatomic material removal. With the passage of time some of these normative acts have lost their topicality and need changes and additions, among them the Law of Ukraine "About transplantation of

The authors indicate no potential conflicts of interest.

Received: January 08, 2014

Accepted: February 03, 2014 organs and other anatomic materials to humans". Some kinds of activity need updating and elaboration of new normative documents. It is only clear-cut regulations and control over activities of organ transplantation that would prevent possible legal infringements in this sphere, incidents with law-protecting bodies thus allowing medical professionals in the field of organ transplantation service in Ukraine work calmly and orderly.

The existing situation with transplantation in Ukraine is regrettably very critical. Despite deep historical traditions, the available cadre and scientific personnel the development of clinical transplantology during last decade was hampered and this field is at stagnation. There is no sense and time to find those who are blame. Rebirth of national transplantation is possible owing to unification of state policy, active work of public and charitable organizations, hard work of medical practitioners and Healthy Ministry staff.

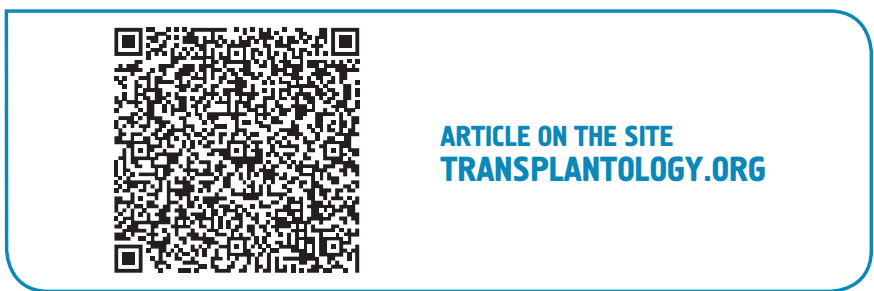

